Pamiętnik Literacki 2015, 3, s. 19-36
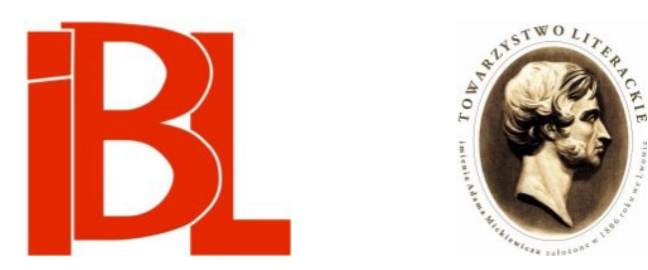

\title{
Papierowa segregacja. Stosunek Marii Dąbrowskiej do Żydów
}

Cyryl Skibiński 


\section{PAPIEROWA SEGREGACJA STOSUNEK MARII DĄBROWSKIEJ DO ŻYDÓW}

Na problem stosunku Marii Dąbrowskiej do Żydów zwraca uwage właściwy jej zwyczaj starannego odnotowywania tego, które spośród osób opisywanych w dziennikach są Żydami albo na Żydów wyglądają. Wskazywanie kogoś palcem nie należy do zachowań szczególnie eleganckich. Można by jednak ten nietakt puścić w zapomnienie, gdyby nie to, że gdzieś z tyłu głowy zaraz rozlega się sygnał alarmowy, wynikający ze skojarzeń związanych z pamięcią o trawiącym II Rzeczpospolita antysemityzmie czy o wybujałym w hitlerowskich Niemczech rasizmie.

Sprawa jest o tyle intrygująca, że Dąbrowskiej w żaden sposób nie da się uznać za stronnika żadnego $z$ prawicowych ugrupowań, które najczęściej łączy się z przedwojennym antysemityzmem. Była przedstawicielką liberalnych, a może nawet lewicujących kregów inteligencji. W młodości duży wpływ miały na nią takie osoby, jak Ludwik Krzywicki czy Edward Abramowski, w latach trzydziestych zaś wiele energii poświęciła na propagowanie idei spółdzielczych, kojarzonych z lewica. Wagi tematowi dodaje też to, że Dąbrowska należała do grona najpopularniejszych literatów okresu międzywojennego. Jej pozycja nie opierała się zresztą wyłącznie na sukcesach literackich - pisarka odgrywała rolę narodowego autorytetu moralnego. Za taki uznawali ją np. - wypowiadając się o tym, co prawda, dopiero po wojnie Konstanty A. Jeleński ${ }^{1}$ i Czesław Miłosz ${ }^{2}$.

Dąbrowska odnotowywała żydowskość przedstawianych osób zarówno wtedy, gdy wspominała o religijnym mieszkańcu małego miasteczka, posługującym się na co dzień językiem jidysz, jak też gdy pisała o spolonizowanym członku inteligencji miejskiej. Jaką wymowę ma ta prowadzona na kartach dzienników i w listach papierowa segregacja? W tej chwili bezpiecznie będzie zatrzymać się na stwierdzeniu, że Dąbrowska wyraźnie odczuwała inność Żydów. Rozważeniu tego, w czym - zdaniem autorki Nocy $i$ dni - owa inność się objawiała, z czego wynikała i jak przekładała się na realia społeczno-gospodarcze, kulturalne i polityczne w przedwojennej Polsce, poświęcam prawie cały niniejszy artykuł. Prawie, albowiem w miarę możliwości chciałbym też znaleźć odpowiedź na pytanie, jak pisarka wyobrażała sobie współżycie Polaków i Żydów w przyszłości.

Relacje polsko-żydowskie w ujęciu Dąbrowskiej ani jej osobisty stosunek do Żydów nie zostały dotąd gruntownie zbadane. Rachel Feldhay Brenner, autorka opublikowanego 4 lata temu na łamach „Slavic Review” artykułu Ideology and Its

1 K. A. J eleńs ki, Aktualność Marii Dąbrowskiej. „Kultura” (Paryż) 1962, nr 6, s. 12.

2 Cz. Miłos z, Zaczynajac od Klamath. Jw., s. 7. 
Ethics: Maria Dąbrowska's Jewish (and Polish) Problem, skupiła sie głównie na reakcji pisarki na Holokaust ${ }^{3}$. Pytanie o stosunek Dąbrowskiej do Żydów leży co najwyżej na marginesie zainteresowań jednego z najbardziej liczących się badaczy jej twórczości, Tadeusza Drewnowskiego ${ }^{4}$. Podobnie jest w przypadku Pawła Rodaka, który w wydanej w 2011 r. książce analizował pod kątem kulturo- i literaturoznawczym diarystykę autorki Nocy $i d n i^{5}$. Problematykę relacji polsko-żydowskich we wczesnej publicystyce społecznej Dąbrowskiej przedstawiła nieco obszerniej Grażyna Borkowska 6 .

Bazę źródłową tego artykułu stanowią: dzienniki pisarki, których pełny tekst opublikowano kilka lat temu nakładem Polskiej Akademii Nauk; publicystyka, którą Dąbrowska parała się od czasów studenckich; wydana korespondencja z mężem, Marianem, oraz przechowywany po części w Muzeum Literatury im. Adama Mickiewicza, a po części w Bibliotece Uniwersytetu Warszawskiego zbiór listów wymienianych ze Stanisławem Stempowskim, długoletnim partnerem życiowym. Za chronologiczną granicę badań przyjąłem wybuch drugiej wojny światowej - choć na niej temat stosunku Dąbrowskiej do Żydów bynajmniej się nie kończy, to w wyniku Holokaustu realia stają się tragicznie odmienne.

Zanim przejdę do części merytorycznej, muszę zrobić jedno zastrzeżenie. W tekście pracy posługuję się prostym podziałem Polak-Żyd. Mam całkowitą świadomość, że w wielu przypadkach nie oddaje to rzeczywistości, zależnej choćby od tego, jak swoją tożsamość definiowała przedstawiana osoba. Stosowane przeze mnie czarno-białe rozróżnienie nie jest w żadnym razie próba przypisania poszczególnych bohaterów tej pracy do polskości lub żydowskości - pełni funkcję wyłącznie istotnego ułatwienia narracyjnego.

\section{Światy równoległe}

W intymnej spuściźnie pisarskiej Marii Dąbrowskiej stosunkowo niewiele miejsca poświęconego jest ortodoksyjnym Żydom ${ }^{7}$, choć to właśnie ludzie religijni, bez świeckiego wykształcenia, odróżniający się ubiorem i często ubodzy stanowili znakomitą większość Żydów w Polsce. Przyczyny takiego stanu rzeczy pośrednio wskazuje sama Dąbrowska, odpowiadając w czerwcu 1960 na list przedstawiciela Stowarzyszenia Żydów Kaliskich (Kalish House) w Tel Awiwie z prośbą o napisanie wspomnienia o przedwojennych żydowskich mieszkańcach Kalisza.

Autorka Nocy i dni, mimo trawiącej ją już wówczas choroby, przesłała w odpowiedzi tekst zatytułowany To, co pamiętam ${ }^{8}$. Ale pamiętała niewiele, gdyż, jak wy-

3 R. F. Bre n ner, Ideology and Its Ethics: Maria Dabrowska's Jewish (and Polish) Problem. „Slavic Review" 2011, nr 2.

4 T. Drewnowski, Rzecz russowska. O pisarstwie Marii Dabrowskiej. Wyd. 3, przejrz. i uzup. Kraków 2000.

$5 \quad$ P. Rodak, Między zapisem a literatura. Dziennik polskiego pisarza $w$ XX wieku (Żeromski, Natkowska, Dabrowska, Gombrowicz, Herling-Grudziński). Warszawa 2011.

$6 \quad$ G. B orkowska, Zaczarowana królewna. U źródet publicystyki społecznej Marii Dabrowskiej. „Teksty Drugie” 2005, nr 6.

7 Do grupy tej zaliczam zarówno wyznawców tradycyjnego judaizmu rabinicznego, jak i chasydów.

8 M. Dąbrowska, To, co pamiętam. Mpis, k. 86-89. Ze spuścizny M. Dąbrowskiej: Artykuły do- 
jaśniała, na przełomie wieków „̇̇ycie Żydów i Polaków płynęło jakby dwoma odseparowanymi strumieniami”. Nastoletnia Dąbrowska wiedzę o obyczajach i realiach codzienności ortodoksyjnych Żydów czerpała głównie z „czytanych z aprobatą” o czym z pewną dumą napomknęła kilka akapitów wcześniej - „żydowskich nowel Konopnickiej, Srula z Lubartowa Szymańskiego, Ogniwa i Meira Ezofowicza Orzeszkowej”. Na kilka lat przed śmiercia pisarka nie mogła wiele powiedzieć o Żydach kaliskich nie dlatego, że pamięć ją zawodziła, ale dlatego, że nigdy ich nie znała. I nie odróżniała się pod tym względem od większości polskiego społeczeństwa ${ }^{9}$.

Pod koniec lat dwudziestych wiedza wyniesiona z lektury nowel Konopnickiej przestała Dąbrowskiej wystarczać. Poważnie wzięła się wówczas do pracy nad powieścią, która po licznych przeróbkach została wydana jako Noce i dnie. Jedną z trzecioplanowych postaci tej epopei jest wędrowny handlarz Szymszel. Wprowadzanie żydowskich bohaterów do utworu (występowała tam jeszcze Arkuszowa, od lat związana z Niechcicami) nie przychodziło jej łatwo. W liście do Stempowskiego prosiła: „Co mówi Szmul, wszystko zapisuj - jakże Ci będę wdzięczna, nawet jeżeli możesz, to mi to przyślij, bo właśnie ciągle $z$ Żydami nie mogę sobie dać rady" ${ }^{10}$. Aby stworzyć bohaterów z krwi i kości, Dąbrowska odwiedzała wioski żydowskie, o czym donosiła Stempowskiemu kilka dni wcześniej ${ }^{11}$.

\section{Tłok, bród i smród}

Fakt, że Maria Dąbrowska starała się choćby „umoczyć nogi” w żydowskim strumieniu, czynił z niej wyjątek wśród polskiej inteligencji. Jednak nawet wejście po kostki w nurt życia ortodoksyjnych Żydów wymagało przełamania tkwiącej w niej odrazy. Jak donosiła w liście do męża:

Najgorzej było do Grodziska, bo w przedziale było 16 osób, w tym 13 Żydów - stłoczeni wszyscy jak pod prasą, stojąc, siedząc, przykucając. Miało to tę jedną dobrą stronę, że przynajmniej nie pluli, gdyż musieliby pluć sobie w chałaty albo wręcz w twarze ${ }^{12}$.

Tłok w ogóle kojarzył się Dąbrowskiej z Żydami. Rozpływając się w liście do męża nad letniskowym osiedlem Wejherowo, gdzie „domki stoją wśród ogrodów na tle lasów i wzgórz”, napisała: „A przy tym, co za swoboda - żadnych Żydów - żadnych znajomych i w ogóle żadnego nigdzie tłoku, żadnych ludzi ze świata"13. Wize-

tyczące zagadnień kultury, literatury i sztuki. Muzeum Literatury im. A. Mickiewicza w Warszawie, Dział Rękopisów, nr inw. 2683.

9 O fakcie odseparowania świata żydowskiego od polskiego w okresie międzywojennym pisze np. Cz. Miłosz, przywołując w swojej Wyprawie w Dwudziestolecie (Kraków 1999, s. 286) opinię wileńskiego dziennikarza M. Goldsztajna.

10 M. Dą brow sk a, list do S. Stempowskiego, z 15 VIII 1928. Ze spuścizny M. Dąbrowskiej: Listy M. Dąbrowskiej do S. Stempowskiego z lat 1925-1946. Bibl. Uniwersytetu Warszawskiego, Dział Rękopisów (dalej: BUW), nr 1564.

11 M. D ą brow s ka, list do S. Stempowskiego, z 12 VIII 1928. Ze spuścizny M. Dąbrowskiej: Odpisy listów M. Dąbrowskiej do S. Stempowskiego z lat 1926-1928. BUW, nr 1565.

12 M. Dą brow s ka, list do M. Dąbrowskiego, z 1 II 1918. W: Ich noce i dnie. Korespondencja Marii i Mariana Dabrowskich 1909-1925. Wstęp, oprac. E. Głę bi ck a. Warszawa 2005, s. 584. 
runek zatłoczonych dzielnic i miasteczek żydowskich uzupełniany jest w spuściźnie Dąbrowskiej informacjami o panującym tam brudzie. Oto jak w 1916 r. scharakteryzowała okolice Bramy Krakowskiej w Lublinie:

Wchodziło się między stare, wąskie i malownicze uliczki, tak wymowne, że nawet odór żydowskich brudów i cebuli nie tamował przystępu romantycznym uczuciom i wyobrażeniom o dawnym życiu, które tutaj niegdyś szumiało. [D-1 75] ${ }^{14}$

Przy bezpośrednim kontakcie $z$ ortodoksami poczucie odrębności wyraźnie przekształcało się u Dąbrowskiej w niechęć powstałą na tle estetycznym - Żydzi utożsamiani byli w jej oczach $z$ trudnym do zniesienia tłokiem, brudem i smrodem. Nie ma powodu, aby nie wierzyć pisarce, iż spotkani przez nią w pociągu Żydzi pluli na podłogę. Trudno jednak nie odnieść przy tym wrażenia, że żydowskie niedostatki higieniczne raziły Dąbrowską bardziej niż polskie. W każdym razie o polskim brudzie nie pisała $z$ taką odrazą. Nie pisała o nim w ogóle, a niewyobrażalne wydaje się to, żeby się z nim nie spotkała. Swojski bród był dla niej do zniesienia, żydowski - nie.

\section{Żydowska egzotyka}

W połowie lat dwudziestych w wypowiedziach Marii Dąbrowskiej odnoszacych się do ortodoksyjnych Żydów pojawił się nowy ton. Przebywając z przyjaciółką w Jamnie, majątku swojej kuzynki, Dąbrowska opisywała Stempowskiemu rozrywki, jakie zapewnia im wiejskie życie:

Nad skrętem rzeki mieszka we wsi nasz słodki poczmistrz Szymszel. Wczoraj niechcący zabłąkałyśmy się z Wandą wprost na jego obejście. Ten skręt rzeki różowy od zachodu, czarna koza na nieużytku, gniade dzieci, czarna piękna żydówa w czerwonej chustce i on sam z łaskawym uśmiechem w karych oczach - wszystko miało w tej sennej płowej wsi charakter egzotyczny i naprawdę jakiś biblijny ${ }^{15}$.

Niewątpliwą nowością w podejściu Dąbrowskiej do Żydów było zatem porzucenie dominującej wcześniej odrazy. Dałoby się nawet powiedzieć, iż pisarka wpadła w inną skrajność. Trudno jednak nie zauważyć, że kreślona przez nią idylla mocno przypomina zachwyty hodowcy nad pięknym koniem (być może maści karej, tak jak oczy Szymszela, lub gniadej, jak włosy czy skóra jego dzieci).

Czy pojawienie się tego typu narracji w notatkach Dąbrowskiej rzeczywiście świadczy o zmianie jej podejścia do ortodoksyjnych Żydów? Odpowiedź kryje się w innym cytacie z dziennika, co prawda późniejszym o 10 lat - z 22 IV 1937. Pisze Dąbrowska o Łaszczowie pod Zamościem:

W ten sposób odsyłam do: M. Dą b r o w s k a, Dzienniki 1914-1965. Pierwsze pełne wyd. w 13 tomach (bez oprac. edytorskiego) pod kier. T. Drewnowskiego. Warszawa 2009. Liczba po skrócie poprzedzona łącznikiem oznacza numer tomu, kolejna - stronicę. Ponadto, odwołując się do dwóch innych książek tejże autorki, posługuję się skrótami: R = Rozdroże. Studium na temat zagadnień wiejskich. (1937). W: Rozdroże. Studium na temat zagadnień wiejskich. - Moja odpowiedź. Refleksje nad polemika z „Rozdrożem”. Warszawa 2009; RU = Ręce w uścisku. Rzecz o spółdzielczości. Warszawa 1938. Następujące po nich liczby wskazują stronice.

15 M. D ą brow s ka, list do S. Stempowskiego, z 15 VII 1926. Ze spuścizny M. Dąbrowskiej: Odpisy listów M. Dą̧browskiej do S. Stempowskiego z lat 1926-1928. BUW, nr 1565. 
Resztki starych bram pałacowych, park, naokoło siedziby wielkopańskiej cztery wysokie kolumny z posągami na szczycie. Wśród tego otoczenia roi się małe brudne miasteczko żydowskie, a raczej osada. Tak żydowska, a w słońcu tak egzotyczna, że mam wrażenie, jakbym była w Małej Azji. [D-4 24]

Egzotyki Szymszela, jego żony i dzieci nie należy się zatem doszukiwać w pięknie ich postaci czy fascynującym kształcie tradycji religijnej, ale w ich cywilizacyjnym zacofaniu, właściwym dla wiosek „Małej Azji czy Afryki”.

Obraz być może fascynującej, jednak cywilizacyjnie zacofanej społeczności żydowskiej znacznie lepiej pasuje do stereotypu opisującego Żydów jako brudnych, śmierdzących i żyjących w ścisku. Warto zwrócić przy tym uwagę, że „egzotyczni” Żydzi spod Lublina wystąpili w reportażu w „nieprawdopodobnej ilości”, ci z Łaszczowa skojarzyli się autorce Nocy $i$ dni z rojem, a jeszcze inne opisane przez nią miasteczko zamieszkiwała „chmara żydków” 16 . Podobne, a po części te same określenia, zrównujące skolonizowanych $z$ insektami, a więc dehumanizujące i odzierające te społeczności z możliwości kulturotwórczych wytyka kolonizatorom Frantz Fanon, w latach pięćdziesiątych XX w. główny ideolog afrykańskich ruchów wyzwoleńczych ${ }^{17}$. Wydaje się, że właściwe „białym panom” jadowite przekonanie o absolutnej wyższości kulturowej nad „czarnym tłumem” ukąsiło również Dąbrowską.

\section{Demaskatorka}

Stosunek autorki Nocy i dni do Żydów ortodoksyjnych można określić jako mieszaninę ignorancji, odrazy i fascynacji żydowska „egzotyką. Tę pełną dystansu reakcję na inność najlepiej chyba nazwać poczuciem obcości. Różnice na polu kulturowym i obyczajowym między ortodoksami a polską inteligencją były tak duże, że owa obcość, wzajemna zresztą, nie powinna nas zaskakiwać. O wiele bardziej zastanawiający wydaje się właściwy Dąbrowskiej zwyczaj skrupulatnego odnotowywania w nawiasach żydowskiego pochodzenia głęboko zasymilowanych osób z jej klasy społecznej. Pierwszego dnia 1928 r. pisarka zanotowała:

Wieczorem na sylwestrze byłam u Kaziów Wierzyńskich. Byli: Lechoń, Szererowie, Breiterowie, Czarski, jakiś młody Sakowski (Seidenbeutel) z twarzyczka piccola z restauracji, przyjaciel Lechonia, jak mówią ludzie znacząco, oprócz tego jakiś pan Heyman〈Heiman〉, panna Konarska (Konówna), podobno bardzo zdolna malarka, i St. Baliński. Wszystkich prawie mało albo wcale nie znałam. Oprócz pierwszego i ostatniego - wszyscy inni - jews. [D-2 53]

Trudno oprzeć się wrażeniu, że za praktyką tą stoi chęć demaskacji ukrytego, obcego oblicza opisywanych osób, nie zaś neutralne emocjonalnie stwierdzenie ich inności. Taki przecież wydźwięk ma staranne odnotowywanie „prawdziwych” nazwisk osób bawiących na przyjęciu u Kazimierza Wierzyńskiego ${ }^{18}$. Potrzeba obnażenia „obcego” dotyczyła przy tym wyłącznie osób żydowskiego pochodzenia. Wskazuje

17 F. F a n on, Wyklęty lud ziemi. Przeł. H. Ty gi i ls ka. Przedm. E. Rekłaj ti s. Posł. J. P. S a r tre. Warszawa 1985, s. 24-25.

18 Dąbrowska popełnia zresztą błąd. „Panna Konarska” to zapewne Janina Konarska, przyszła żona Antoniego Słonimskiego, która rzeczywiście często bywała u Wierzyńskich. $Z$ tego powodu plotkowano nawet o romansie Konarskiej i Wierzyńskiego. Jej poprzednie nazwisko brzmiało jednak Seideman, a nie Kon. 
na to chociażby fakt, iż Dąbrowska nie napomknęła wspominając sylwestrową noc u Wierzyńskich, że „prawdziwe” nazwisko gospodarza brzmiało Wirstlein, a ojciec jego był osiadłym w Galicji Niemcem, który zapewne nie przemawiał do syna literacką polszczyzną.

\section{O obcych w obcym języku}

Odnotowując etniczne pochodzenie gości bawiących podczas sylwestrowej nocy u państwa Wierzyńskich, pisarka zastąpiła słowo „Żydzi” angielskim określeniem „jews" (zawsze mała litera). Od roku 1926 jest to jej stała praktyka tak w dziennikach, jak w prywatnych listach, choć nie robi tego w pełni konsekwentnie ${ }^{19}$. Trudno dociec, dlaczego Dąbrowska akurat wtedy zaczęła używać angielskiego zastępnika. Ważniejsze zresztą wydaje się pytanie nie dlaczego wówczas zaczęła stosować ten zastępnik, ale w ogóle dlaczego Dąbrowska starała się unikać określenia „Żyd”. Na właściwy trop naprowadzają jego słownikowe definicje.

Drugie, przenośne znaczenie wyrazu „Żyd” odnotowane w Słowniku Warszawskim brzmi: 'człowiek, którego religia pieniądz; szachraj, handlarz, kramarz, tandeciarz; człowiek wyrachowany, lichwiarz, kutwa, skąpiec, chciwiec, zdzierca, wyzyskiwacz’. Definicję tę zilustrowano m.in. następującym zdaniem: „Przezwisko [Żyd] niekoniecznie oznacza wyznawcę mojżeszowego; dawane jest ludziom chciwym, przebiegłym, szukającym zysku”20. Wydaje się więc, że pisząc „jew” zamiast „Żyd” wykazywała się Dąbrowska delikatnością. Nie kalała stronic swego dziennika ani arkuszy listowych słowem, które pełniło wówczas funkcję obelgi (w pewnych środowiskach pełni ją także dziś). Można też przypuszczać, że ów pojęciowy kamuflaż miał w jej własnych oczach rozmiękczyć nieco praktykę wskazywania Żydów palcem, co musiało jej się przecież kojarzyć z zajadłym, endeckim antysemityzmem.

Chociaż w twórczości intymnej Dąbrowskiej nie ma wulgarnych zwrotów bezpośrednio odnoszących się do żydowskości opisywanych osób ${ }^{21}$, to nie brakuje tam fraz, które potraktować trzeba jako wymierzony Żydom policzek. Opisujacc Stempowskiemu w rok po wojnie spotkanie ze znajomą Anny Kowalskiej, lekarką, która w czasie okupacji wystawiła jej fałszywe świadectwo, że jest chora na tyfus, Dabrowska tak skwitowała swojego dobroczyńcę: „Jest to jew, ale bardzo przyjemna - egzaltowana w rodzaju Ani”22. Frazy typu „Żyd, ale miły” czy „miły, chociaż Żyd” wydają się trwałymi elementami przedwojennej polszczyzny i wskazują na ukryty w niej potencjał niechęci wobec Żydów. Dąbrowska, niezwykle świadoma użytkowniczka języka polskiego, w prywatnych zapiskach nie unikała tych form.

Najwcześniejszy zauważony przeze mnie przypadek znajduje się w liście M. Dąbrowskiej do S. Stempowskiego z 21 XII 1926 (Ze spuścizny M. Dą̧rowskiej: Listy M. Dąbrowskiej do S. Stempowskiego $z$ lat 1925-1946. BUW, nr 1564).

20 Żyd. Hasło w: J. Karłowi cz, A. Kryński, W. Niedźwiedzki, Słownik języka polskiego. T. 8. Warszawa 1935, s. 732.

21 Jedynym tego typu określeniem, na jakie trafiłem, jest „żydłak”, ale pojawia się ono tylko raz, i to w odniesieniu do osoby, która zrobiła na Dąbrowskiej dobre wrażenie - zob. D-1 191 (zapis z 23 III 1920).

22 M. Dąbrowska, list do S. Stempowskiego, z 8 VII 1946. Ze spuścizny M. Dąbrowskiej: Listy M. Dąbrowskiej do S. Stempowskiego z lat 1925-1946. BUW, nr 1564. 


\section{Trefna fizjonomia}

Różnice dzielące społeczności polską i ortodoksyjnych Żydów same rzucały się w oczy. Co Dąbrowska chciała przekazać, podkreślając w nawiasach pochodzenie swoich głęboko spolonizowanych znajomych, jest mniej oczywiste. Nie chodziło przecież o religię, bo w Dwudziestoleciu międzywojennym, a właściwie od czasów XIX-wiecznej emancypacji Żydów, kwestia religijna nie była już wystarczającym kryterium żydowskości. W czym więc przejawiały się, w rozumieniu pisarki, dzielące Żydów i Polaków różnice i jaki miała do nich stosunek?

Autorka Nocy $i$ dni szczególną uwagę zwracała na „semickie” rysy twarzy napotykanych ludzi. W liście do Stempowskiego, w taki sposób opisywała Jerzego Czopa, dyrektora uzdrowiska w Jaworzu, w którym właśnie przebywała:

Czop wczoraj wrócił i spędził z nami niedzielę. Dosyć długo z nim rozmawiałam i przypatrzyłam mu się. Już teraz zaczyna być widać żydowskie cechy jego wyglądu nawet dla nie wiedzącego - trochę mi przypomina tego pięknego żydka, który stoi na fotografii zbiorowej przedstawiającej Kadenów w pokoju przy biurku - jeśli pamiętasz ${ }^{23}$.

Dąbrowska poświęciła sporo czasu, aby wreszcie dopatrzyć się żydowskich cech w fizjonomii Czopa. Czytając ten fragment, trudno nie odnieść wrażenia, iż bardzo pisarce na tym zależało, choć nie było to łatwe.

Warto zauważyć, że do „faktu” żydowskiego wyglądu Czopa odnosi się Dą̧browska raczej afirmacyjnie. Niewykluczone zresztą, iż wpływ na ocenę Czopa miały także inne względy poza antropometrycznymi, bardziej natury emocjonalnej, o czym może świadczyć to, że pisarka niedługo później wdała się z nim w długotrwały romans. Na co dzień jej ocena była odmienna. Swoje wrażenia $z$ wizyty w Zachęcie przedstawiała 2 III 1920 następująco:

Równie bardzo piękny, malarz całą gębą, Weiss, chociaż strasznie żydowskie wszystkie jego typy. Zwłaszcza Rodzina przy stole świetnie namalowana, tylko że można by pod tym podpisać: „Typowa żydowsko-burżuazyjna rodzina w Polsce”. [D-1 190]

Żydowski wygląd namalowanych postaci zdawał się psuć efekt artystyczny. Stąd dość logicznie brzmi przekonanie autorki, że Żyd nie wyglądający na „Semitę” może to sobie poczytywać za zasługę. Pod datą 17 I 1938 pisarka zanotowała:

Poznaję Ostapa Ortwina (Katzenellenbogen, rodzony wuj pani Blum. ${ }^{24}$ ), który jest podobny do Ignacego Chrzanowskiego i nic nie wygląda na Żyda. To też tylko lwowscy Żydzi potrafią. [D-4 64]

\section{Mentalność Wernera Sombarta}

Różnice dzielące Polaków i spolonizowanych Żydów nie dotyczą, zdaniem Dąbrowskiej, tylko ich urody, ale czegoś głębszego, a przy tym bardziej uniwersalnego. W latach dwudziestych i trzydziestych toczyła się w Polsce dyskusja o - zagrażającej polskości - agresywnej kulturze żydowskiej. Choć autorka Nocy i dni nie brała udziału w owych sporach i nie było to zagadnienie, które trawiła w mękach podczas 
nocy nieprzespanych ze strachu przed „zażydzeniem” polskiej kultury, to w pewnym momencie dostrzegła cechy specyficznie żydowskie m.in. w poezji Bolesława Leśmiana (zob. D-4 57 〈28 XII 1937〉). Skąd owe cechy w twórczości literata wychowanego w kulturze polskiej? Dąbrowska musiała zakładać istnienie mentalności wspólnej dla ogółu Żydów czy - jak pisała - „psychiki żydowskiej”25. Gdzie jest źródło szczególnego charakteru właściwego, zdaniem Dąbrowskiej, wszystkim Żydom: czy wynikał on z przynależności do określonej kultury i wspólnoty doświadczeń (stanowił reakcję np. na antysemityzm), czy był raczej cechą wrodzoną u ludzi należacych do „rasy semickiej”?

Wobec skapaści materiału trudno o pewność co do kształtu poglądów Dąbrowskiej na omawiane kwestie, ale wskazówkę stanowi streszczone przez nią dzieło Wernera Sombarta Żydzi i życie gospodarcze ${ }^{26}$. Artykuł młodej publicystki niemal pozbawiony jest komentarza krytycznego i napisany tak, że chwilami trudno odróżnić tezy Sombarta od uzupełniających je opinii autorki streszczenia. Tekst ukazał się w 1913 r. w dwóch odcinkach na łamach „Prawdy”, jednego z ważniejszych czasopism postępowej inteligencji polskiej ${ }^{27}$.

Główna teza zawarta w książce Sombarta mówi, że Żydzi mieli dominujący wpływ na powstanie kapitalizmu. Była to zatem swojego rodzaju odpowiedź na pracę Maxa Webera Etyka protestancka a duch kapitalizmu (1905). Sombart nie poprzestał jednak na badaniu oddziaływania judaizmu na gospodarkę - dwa rozdziały swojego dzieła poświęcił na zupełnie bezwartościowe $z$ punktu widzenia dzisiejszej nauki omówienie wpisanej w kapitalizm „istoty żydowskiej”. Autor Żydów i życia gospodarczego wyznaczył cztery główne składowe tejże „istoty”: intelektualizm, teleologizm, woluntaryzm (energizm) i mobilizm ${ }^{28}$, przy czym pierwszy element uważał za podstawowy.

W światopoglądzie Dąbrowskiej „naczelna cecha istoty żydowskiej” także odgrywała pewną rolę. W cytowanym już liście, w którym Dąbrowska opisywała Stempowskiemu wygląd Czopa, znalazł się też ustęp dotyczący jego intelektu. Jak wiemy, Czop był przystojny, choć przedstawiał nieco „semicki typ urody”, jednak „inteligencja jego [...] jest dziwnie zdawkowa jak na żydowska”29. Ze zdania tego wynika jasno, że - według Dąbrowskiej - żywa inteligencja stanowi cechę ogółu Żydów, a Czop znajduje się pod tym względem poniżej żydowskiej normy.

Podobne opinie zdarzało się autorce wypowiadać niejednokrotnie. Ciekawe, że ich forma opierała się zwykle na przedstawianiu wyjątków od reguły. Już po wojnie, 22 II 1955, Dąbrowska takimi słowami kończyła opis wrażenia (bardzo niekorzystnego), jakie wywarł na niej poznany tego dnia Julian Stryjkowski: „Pierwszy [...] raz widzę Żyda, który byłby tak mało atrakcyjny, prymitywny i nieinteligentny"

D ąbrowska, To, co pamiętam.

W. S o m bar t, Die Juden und das Wirtschaftsleben. Leipzig 1911. Możliwe, że Dąbrowska korzystała z polskiego tłumaczenia M. B ro k ma now ej, które ukazało się w 1913 roku.

M. D ą b r ow s ka, Judaizm a kapitalizm. (Wedtug W. Sombarta). „Prawda” 1913, nry 7, 9.

Za podstawę biorę zasadniczo poprawne streszczenie poglądów Sombarta pióra Dąbrowskiej. Ponieważ interesuje mnie opinia pisarki o ówczesnym kształcie stosunków polsko-żydowskich, nie są problemem potencjalnie popełnione przez nią błędy w interpretacji myśli niemieckiego autora. Nie próbuję zatem konfrontować streszczenia $\mathrm{z}$ oryginałem.

D ą b row s ka, list do Stempowskiego, z 15 X 1929. 
(D-9 152). Zwyczaj wskazywania wyjątków zdaje się świadczyć o tym, że istnienie szczególnie dużych możliwości żydowskiego intelektu uważała pisarka za oczywistość.

\section{U wrót rasizmu}

Sombart uznawał „istotę żydowska” za zespół cech właściwych nie grupie społecznej, ale rasie. Mentalność powstałą na gruncie takich czynników, jak religia czy wędrowny tryb życia („nomadyzm”), współcześni mu Żydzi mieli, jego zdaniem, we krwi. Niezależnie zatem od tego, czy Żyd przyjął chrzest lub od pokoleń żyje w innej niż żydowska kulturze, zachowuje on dziedziczona po przodkach, niezmienną żydowskośćc ${ }^{30}$. Stwierdzając istnienie charakteryzującej Żydów wysoko rozwiniętej inteligencji Dąbrowska zdaje się jednoznacznie wpisywać w tę narrację. Jeżeli wszakże ową żydowską inteligencję rozumieć nie jako wrodzoną fizyczną cechę mózgu, ale właśnie intelektualizm, czyli - zakorzenione w kulturze i, być może, mentalności - przywiązanie do wartości, jaka jest wyrobienie intelektualne, to sprawa wygląda inaczej. W takim wypadku należałoby raczej mówić o tendencji Dąbrowskiej do absolutyzowania wpływu kultury na psychikę i o zbytniej wierze w jego trwałość.

Przyjmując nawet, że pisarka posługiwała się kategoriami rasowymi, trzeba pamiętać, iż na owe czasy nie było to w żaden sposób wyjątkowe. Kwestia różnic dzielących rasy należała na początku XX w. do zagadnień głównego nurtu nauki akademickiej. Odbicie tej dyskusji widać np. w tekście publicystycznym Janusza Korczaka z 1933 r. zatytułowanym Dziecko żydowskie, z odredakcyjnym podtytułem Opinia rzeczoznawcy ${ }^{31}$. Autor, którego trudno posądzić o antysemityzm, nie wykluczył bynajmniej istnienia genetycznie zakodowanych różnic psychicznych i fizycznych między „dziećmi księgi” a „dziećmi pługa”. Nie zaprzeczył też, że jest możliwe - co byłoby zgodne ze stereotypem - iż dzieci żydowskie są inteligentniejsze. Swoje niejednoznaczne odpowiedzi tłumaczył niewiedzą wynikającą z braku rzetelnych badań. I choć dziś duża część jego opinii nie wydaje się nam zadowalająca, to wobec ówczesnego stanu nauki nosiły one przecież znamiona zdrowego rozsądku.

Dąbrowska, podobne jak Korczak, była świadoma, iż porusza się po grząskim gruncie. $Z$ jednej strony, nie miała wątpliwości, że istnieje semicki typ urody, wierzyła w szczególne uzdolnienia intelektualne Żydów. $Z$ drugiej - w swojej spuściźnie intymnej praktycznie nie używa nazwanych wprost kategorii rasowych: „Semitów” i „Aryjczyków” jest tam jak na lekarstwo. Określenia te bardzo rzadko pojawiają się nawet w latach trzydziestych, kiedy w Polsce triumfy święciło przywleczone z Zachodu myślenie rasistowskie.

Podejrzenie o stosowanie kategorii rasowych, jakie pada na autorkę Nocy i dni, nie jest równoznaczne $z$ oskarżeniem o rasizm. Przekonanie o istnieniu zakodowanych we krwi różnic na tle psychicznym czy fizycznym - jeżeli Dąbrowska rzeczywiście w nie wierzyła - nie musi wiązać się z negatywnym ich wartościowaniem 
i uznaniem wyższości jednej rasy nad drugą. W przypadku pisarki można by zresztą mówić raczej o uznaniu wyższości niezwykle inteligentnej rasy semickiej. Pogląd ten, przyjęty za pewnik także przez część antysemitów, mobilizował ich do jeszcze bardziej zapalczywej walki w „obronie” - poszkodowanego przez naturę - własnego narodu. Dąbrowska była wszelako od takiego sposobu myślenia daleka: zwalczała ideologię rasistowską, prześmiewając terrorystyczne praktyki „domorosłych rasistów” (RU 85).

\section{Historyczna wina szlachty}

Do tej pory pisałem głównie o tym, jak autorka Nocy i dni postrzegała Żydów i jaki miała do nich osobisty stosunek. Warto przyjrzeć się także temu, w jaki sposób odnosiła się do owej grupy jako całości. W gruncie rzeczy jest to pytanie o to, jak publicystka Dąbrowska zapatrywała się na „kwestię żydowska”. Najwięcej materiału przydatnego do badania tego zagadnienia dostarczają dwie głośne broszury jej autorstwa. Wydane w 1937 r. Rozdroże. Studium na temat zagadnień wiejskich dotyczyło potrzeby przeprowadzenia reformy rolnej, a właściwie nadania przyjętym już przez Sejm uchwałom odpowiedniego zasięgu i tempa. Rok późniejsze Ręce $w$ uścisku stanowiły natomiast obronę - niepopularnych w kręgach konserwatywnych - idei spółdzielczych.

Choć dziś związki „kwestii żydowskiej” z reformą rolną czy spółdzielczością mogą wydawać się nieoczywiste, to w obu publikacjach autorka poświęciła Żydom sporo miejsca. Fundamentem „kwestii żydowskiej” było - zdaniem Dąbrowskiej - to, że społeczeństwo żydowskie „miało w swoich rękach bardzo znaczną część całego dochodu społecznego Polski, prawie cały handel hurtowy i drobny oraz znaczna część przemysłu”32, co łączyło się ze „słabością gospodarczą żywiołów rodzimych” (R 57). Wizja pisarki nie była zupełnie oderwana od rzeczywistości. Wskazuje na to choćby opracowane przez Jerzego Tomaszewskiego zestawienie dla r. 1931, z którego wynika, że Żydzi stanowili większość osób utrzymujących się z handlu detalicznego i niemal połowę w przemyśle odzieżowym i skórzanym ${ }^{33}$. Alina Cała, ujmując sprawę w sposób bardziej ogólny, stwierdza nawet, iż w pierwszych dekadach XX w. Żydzi „w dużym stopniu nadal odgrywali rolę stanu trzeciego”34.

Broszury Dąbrowskiej przynoszą odpowiedzi na pytania, skąd wzięła się domniemana supremacja Żydów w życiu gospodarczym i jak ten stan rzeczy naprawić. Analiza historyczna gospodarczej pozycji Żydów w Polsce zawarta została głównie w Rozdrożu, które wbrew podtytułowi dotyczy także zagadnień miejskich, nie oderwanych oczywiście od problemów wsi. Tezą Dąbrowskiej jest, że to „my sami” - tzn. Polacy - odpowiadamy za powstanie „kwestii żydowskiej”. A szczególna odpowiedzialność spoczywa na warstwach historycznie uprzywilejowanych, czyli na szlachcie i ziemiaństwie.

Największą w minionych wiekach bolączkę polskiego życia gospodarczego stanowiło, zdaniem autorki Rozdroża, złe prawodawstwo rolne, które „związawszy

J. To m a s z e w s ki, Zarys dziejów Żydów w Polsce $w$ latach 1918-1939. Warszawa 1990, s. 25.

A. C a ła, Żyd - wróg odwieczny? Antysemityzm w Polsce i jego źródła. Warszawa 2012, s. 286. 
chłopa pańszczyzną i przepełniwszy wieś biedotą, nie dopuściło zarazem do rozwoju mieszczaństwa polskiego" (R 51). Ponieważ szlachta robiła wszystko, żeby utrzymać pańszczyznę i ograniczyć ruchliwość chłopów -

dalszą pracę nad rozwojem zajęć miejskich podjęli w przeważnej części Żydzi, którym w tej działalności nie tylko nie przeszkadzano, lecz, owszem, pomagano, których nawet na tę działalność niejako skazywano, zabraniając im jakiejkolwiek bądź innej. [R 53]

Wkrótce na skutek lenistwa i przesądów nie pozwalających szlachcie kalać się handlem (fakt, że wiązałoby się to $\mathrm{z}$ utratą tytułu nie był w oczach pisarki usprawiedliwieniem) panowie zaczęli ściągać Żydów także na wieś. Jednak postępujące rozdrobnienie ziemi chłopskiej i „zacofane stosunki ekonomiczno-kulturalne” spowodowały podupadanie dóbr szlacheckich. Skutek był taki, że „Żydzi zawładnęli tam nie tylko częścią ziemi chłopskiej (za wódkę), ale i dobrami szlacheckimi” (R 67-68). Powstała w ten sposób tradycja kupiecka i wypracowany kapitał pozwolił później rodzinom żydowskim inwestować w rodzący się na ziemiach polskich przemysł. Tak oto zaistniała „kwestia żydowska”.

Chociaż na pierwszy rzut oka widać, że przedstawiona przez Dąbrowską analiza historyczna nie jest wolna od pewnych uproszczeń czy uprzedzeń - jak wizja Żydów łupiących chłopów za pomocą wódki - to nie czas na jej dogłębną krytykę. Warto podkreślić jednak to, że autorka Rozdroża i Rak $w$ uścisku zupełnie zrezygnowała $z$ powielania - pojawiajacych się w jej dziennikach czy listach - opinii o szczególnych uzdolnieniach Żydów, które pozwalają im odnieść sukces ekonomiczny, czy choćby z przekonania o wyjątkowej inteligencji ich cechującej. Całość wywodu pisarki opiera się na wskazaniu uwarunkowań społecznych, które wpłynęły na rolę odgrywaną przez ludność żydowską w życiu gospodarczym.

Ważnym elementem analizy Dąbrowskiej wydaje się teza, że to nie Żydzi odpowiedzialni są za powstanie „problemu żydowskiego”. W Rozdrożu czytamy:

[...] Żydzi, tak samo jak inni obcokrajowcy, nie najechali nas gwałtem, tylko za naszą bardzo pochopną zgodą wykonali za nas - jak mogli, chcieli i umieli - konieczną robotę stworzenia handlu i przemysłu. [R 55]

Za „uniewinnieniem” Żydów, mimo wyrażonej w przywołanym cytacie wobec nich niechęci, idzie też podważanie polskich względem nich zasług - autorka podkreśla, że stosunkowo łagodne, na tle innych krajów europejskich, traktowanie Żydów nie wynikało $z$ humanitaryzmu szlachty, ale $z$ tego, że oferowane przez nich usługi były panom potrzebne (zob. R 53). Nie widziała zresztą sytuacji społeczności żydowskiej w dawnej Polsce w różowych barwach. Ludność ta bowiem -

miała w Polsce większe prawa niż polscy chłopi, a jednocześnie była pogardzana i pomiatana tak samo jak chłopi. Z życia zaś ogólnego była wyosabniana przez nas jak trędowaci, a wyosabniała się sama jako naród wybrany. [R 57]

Pisarka uderzała więc w mit Polski jako raju dla Żydów i w propagowane przez antysemitów twierdzenie, że „problem żydowski” wynika ze zbyt łagodnego traktowania Żydów w minionych stuleciach ${ }^{35}$. 


\section{Pozytywne rozwiązanie „kwestii żydowskiej”}

Problem podniesienia jakości życia na wsi to dla Dąbrowskiej coś więcej niż tylko zagadnienie społeczno-gospodarcze. Jeszcze w czasach rozbiorowego zniewolenia młoda publicystka pisała, że koniecznościa jest nie tylko odzyskanie niepodległości - „mamy pod osłoną krwi zdobytego polskiego państwa stworzyć na nowo N a ród z luźnej, zepsowanej, rozproszonej po świecie gromady" 36 . Drogę wiodącą do tego ambitnego celu widziała w osiagnnięciu trwałej pomyślności gospodarczej i „uobywatelnieniu” najliczniejszej części społeczeństwa, czyli chłopów. Tadeusz Drewnowski uważa, że choć „tworzenie Narodu na nowo” brzmiało początkowo jak „dziennikarski slogan, okazało się programem całego życia [...]"37. Najpełniejszym wyrazem tego programu było, zdaniem badacza, największe dzieło literackie Dąbrowskiej, gdyż „Tradycja eks-szlacheckich i wiejskich domów przemienia się w Nocach i dniach w nowa tradycję demokratyczną" 38 .

Kilka lat później, pisząc Rozdroże i Ręce $w$ uścisku, Dąbrowska nadal widzi przyszłość w przeobrażeniu Polski w „kraj chłopski i oparty na drobnej własności rolnej” (R 70) oraz podtrzymuje tezę:

W tej chwili [...], mimo trwania nadal nieprzyjaznych okoliczności, chłop jest elementem cywilizacyjnym o takim napięciu twórczej siły, jakie przejawiał naród polski jedynie w najbardziej dynamicznym, piastowskim okresie swych dziejów. [R 141]

Rodzi się pytanie, czy przypadkiem owa „twórcza siła” w dążeniu do dobrobytu nie musiała skumulować się przeciw Żydom?

Dużej części społeczeństwa wydawało się to oczywiste. Sposobem na „unarodowienie handlu" i przygotowanie w miastach miejsca dla emigrantów z przeludnionych wsi był bojkot sklepów żydowskich, który łączył się $\mathrm{z}$ wybijaniem w nich szyb oraz z innymi szykanami wobec właścicieli sklepów i kramów. Pomysł Dąbrowskiej na rozwiązanie „kwestii żydowskiej” przedstawiał się inaczej. „Niedorozwój gospodarki narodowej” miał nastąpić dzięki „dźwignięciu mas chłopskich”. Polepszenie sytuacji ekonomicznej na wsi miało być efektem reformy rolnej, zakładającej parcelację ziemi (oraz jej komasację) na rzecz drobnych gospodarstw małorolnych (zob. R 56). W ten sposób mogła uwolnić się „twórcza siła” u dwóch trzecich, jak obliczała, narodu polskiego (zob. R 105). Na reformie rolnej straciłaby więc co najwyżej warstwa ziemiańska (odpowiedzialna za „zażydzenie” miast i ruinę chłopa), ale nie sami Żydzi.

Drugim kluczowym elementem reorganizacji polskiego życia gospodarczego zarówno na wsi, jak i w mieście - był rozwój spółdzielczości. Jej zaleta polegała na tym, że nie opierała się ona na wkładzie pieniężnym „banków prywatnych ani wielkich kapitalistów”. To jednak nie koniec, „rzecz najdonioślejsza” streszcza się w tym, że:

nie ma w nim [tj. w dorobku spółdzielczym] kapitałów inwestycyjnych obcych ani zagranicznych, na

M. Dą br ow ska, O czerwony postaw. „Krytyka” 1913, t. 39. Cyt. za: D r ew now ski, op. cit., s. 83.

Drewnowski, op. cit., s. 359.

Ibidem, s. 189. 
których stoi przecież, niestety, całe prawie życie przemysłowo gospodarcze, organizowane w Polsce przez przedsiębiorców prywatnych. [RU 5]

Uwagę zwraca rozróżnianie przez Dąbrowską kapitału „obcego” i „zagranicznego”. Znaczenie tego drugiego jest jasne. Kapitałem „obcym” dysponują natomiast, jak bez żadnych wątpliwości wynika $z$ kontekstu całego rozdziału, osiadli w Polsce Niemcy, a przede wszystkim polscy Żydzi. Gdy mowa zatem o „niedorozwoju gospodarki narodowej”, chodzi wyłącznie o udział w nim „żywiołów rodzimych”, a nie o jakość gospodarki państwowej.

Na czym jeszcze, poza pominięciem wielkiego żydowskiego kapitału, polegał antyżydowski wymiar spółdzielczości? Organizacja spółdzielcza pozwalała na skuteczniejsze konkurowanie z Żydami na polu handlowym, co było trudne, gdyż zdaniem Dąbrowskiej - Żydzi reprezentowali głębiej zakorzenione w tradycji zamiłowanie do kupiectwa niż Polacy (zob. RU 90). Jednym $z$ fundamentalnych celów spółdzielczości jest zwiększenie dochodu producentów przy równoczesnym minimalizowaniu cen dla kupujących poprzez wyeliminowanie pośredników. W przedwojennej polskiej rzeczywistości znaczna część pośredników - a przynajmniej tak sądziła pisarka - była Żydami ${ }^{39}$.

Dąbrowska określa program poprawy statusu ekonomicznego „żywiołów rodzimych" - przedstawiony w Rozdrożu i Rękach w uścisku - jako godziwy, gdyż w pełni „pozytywny” (RU 56). Pozytywny, czyli oparty na działaniach nie zmierzających do podniesienia Polaków kosztem Żydów, ale do twórczego zdynamizowania polskiego życia gospodarczego i włączenia w struktury rynkowe (nie kapitalistyczne) ludzi do tej pory stojących poza nią (zob. RU 86). Rozwijająca się spółdzielczość tak samo uderzała przecież w hurtowników żydowskich, jak i w polskich. Nie można więc powiedzieć, że jej istotą była antyżydowskość.

Jak ma się do tego natarczywie eksponowany w broszurach Dąbrowskiej antyżydowski wymiar reformy rolnej i spółdzielczości? Choć autorka deklarowała, że uprzykrzenie życia Żydom nie jest istota jej postulatów, nie można jednak oprzeć się wrażeniu, iż stanowiło ono wartość dodaną. Trudno ocenić, w jakim stopniu wynikało to z przekonań pisarki, a w jakim stanowiło odpowiedź na oczekiwania czytelników. Broszury te adresowane były przecież do niechętnych zarówno reformie rolnej, jak i spółdzielczości środowisk konserwatywnych oraz tych związanych z endecją. A obie idee kojarzyły się raczej $z$ lewica, więc aby zyskać jakąkolwiek szansę przekonania do nich osób lokujących się na przeciwnym krańcu politycznego spectrum, Dąbrowska musiała zetrzeć $z$ nich czerwony nalot. Wyeksponowanie elementów postulowanych reform uderzajacych w Żydów nadawało się do tego doskonale. Stapając po granicy oddzielającej publicystyczną skuteczność od cynizmu, Dąbrowska jednak bez żadnej taryfy ulgowej podważa skuteczność i piętnuje działania prawicy:

Nasi domorośli rasiści walczą dziś ze sklepami spółdzielczymi w imię hasła... unarodowienia handlu. $[\ldots]$

Trudno o większy splot nieporozumień i paradoksów. Cóż bowiem uczynili dla unarodowienia 
handlu ci, co najgłośniej o nim krzyczą, bijąc szyby żydowskich sklepów? Od terrorystów tego rodzaju niepodobna zresztą wymagać żadnej myśli nie tylko rozumnej, lecz chociażby przytomnej. [RU 85]

Kilka linijek dalej wyjaśnia, na czym owa nierozumność polega:

W Polsce nie istnieje czysty handel polski i czysty handel żydowski. W Polsce istnieje prywatny handel polsko-żydowski tak ściśle ze sobą splątany, związany i zrośnięty, że żadne mechaniczne ani raptowne sposoby nie zdołaja go $z$ dnia na dzień bez najsroższego szwanku także i dla polskiego kupiectwa rozdzielić, oraz istnieje wymiana i wytwórczość organizowana według zasad spółdzielczych, która jest jedynym czysto polskim ośrodkiem handlowo-przemysłowym. [RU 86]

\section{Państwo wielonarodowe}

Drewnowski napisał w jednym $z$ esejów, że autorka Nocy $i$ dni upatrywała „rozstrzygnięcie kwestii żydowskiej [...] w rozwiązaniach skrajnych: albo asymilacja - albo emigracja”. Jego zdaniem, Dąbrowska odrzucała perspektywę powstania w Polsce „światłej i lojalnej mniejszości obywateli polskich narodowości żydowskiej”, gdyż świeżo odrodzony kraj nie udźwignąłby obciążenia wynikającego $z$ pożycia na jego terenie dwóch narodów ${ }^{40}$. Badacz dodaje jeszcze, że pisarka podchodziła co najmniej sceptycznie do szans na pełne przeprowadzenie obu tych projektów, choć pracując piórem, robiła wszystko, aby asymilacja mogła przebiegać sprawnie ${ }^{41}$. Forma eseistyczna tekstu nie wymagała od znakomitego badacza literatury, aby podał źródła, na jakich oparł swoje opinie (a poniekąd nawet mu to uniemożliwiła). Wielka szkoda - mnie nie udało się znaleźć materiałów sugerujących, żeby pisarka popierała ideę emigracji czy niemodną już w II Rzeczpospolitej myśl o asymilacji Żydów. Co więcej, przedstawiona przeze mnie teza, oparta na przekonaniu, że Dąbrowska sprowadzała „kwestię żydowską” do problemu „słabości ekonomicznej żywiołów rodzimych", zdaje się wskazywać na coś dokładnie odwrotnego.

Cała zwraca uwagę, że dla prawicowej części opinii publicznej „kwestia żydowska" była nierozwiązywalna w granicach państwa. Problemu dla tej grupy ludzi nie stanowił bowiem, jak w przypadku Dąbrowskiej, jakiś zespół bolączek społeczno-gospodarczych; stanowili go sami Żydzi ${ }^{42}$. Żeby zniknął problem, zniknać musieli Żydzi - czy to przez całkowita polonizację (co dla części środowisk prawicowych jawiło się jako koszmar), czy właśnie przez emigrację. „Kwestia żydowska” taka, jaką widziała ją Dąbrowska, mogła być natomiast w przyszłości, mniej lub bardziej odległej, rozwiązana. A skoro tak, pisarka musiała zakładać, że możliwe jest pożycie dwóch narodów w ramach jednego państwa (w sytuacji Polski liczbę narodów wypadałoby zresztą co najmniej podwoić). O słuszności owego założenia upewnia nas też to, w jaki sposób Dąbrowska podchodziła do mniejszości narodowych białoruskiej i ukraińskiej. W Rękach $w$ uścisku stwierdzała:

Dziś za polski stan posiadania uważać musimy także stan posiadania rdzennej ludności ukraińskiej, jako ściśle i nierozerwalnie przynależnej do państwa polskiego, zobowiązanego dbać o inte-

T. D r e w n ow s ki, Węzty nie rozsupłane. W: Wyprowadzka z czyśćca. Burzliwe życie pośmiertne Marii Dabrowskiej. Warszawa 2006, s. 187.

41 Zob. ibidem, s. 184.

$42 \quad$ Cała, op. cit., s. 281. 
resy tej mniejszości z taką samą pieczołowitością jak o interesy Polaków ziemie te zamieszkujących. [RU 60]

Fragment ten może sugerować, że pisarce marzyło się spolonizowanie Białorusinów czy Ukraińców, dalszy ciąg rozwiewa jednak owe przypuszczenia:

Wzajemne odwracanie się do siebie plecami dwu odłamów ludności, przez wieki historii w tych stronach ze sobą przemieszanych, nie może leżeć ani w intencjach, ani w interesie państwa polskiego. Tak samo jak nie leżałoby w tym interesie wynaradawianie Ukraińców, nie mówiąc już o nieuniknionej moralnej i życiowej kompromitacji takiego przedsięwzięcia. [RU 60]

Za tymi słowami kryje się więc bez wątpienia nadzieja Dąbrowskiej na powstanie państwa wielonarodowego, zamieszkanego przez świadomych obywateli, mających pełne prawo kultywowania swoich tradycji. Pisarka przestrzega nawet, że jeżeli tak się nie stanie, „będzie to największym niebezpieczeństwem dla bytu Polski w ogóle”, gdyż przypominając „groźny wulkan”, spali się w wewnętrznych konfliktach narodowościowych (zob. RU 60).

Klarowność sytuacji burzy jednak to, że Dąbrowska, odmalowując wymarzony obraz społeczeństwa wielokulturowego, zdaje się pomijać Żydów ${ }^{43}$. Rzeczywiście, nawet w dość wyczerpującym studium nad sytuacją mniejszości w Polsce, jakie zostało zawarte w Rękach $w$ uścisku, autorka skupia się niemal wyłącznie na mniejszościach „rusińskich”. Przyjmując - co starałem się wykazać - że Dąbrowska nie projektowała w Polsce antyżydowskiego systemu gospodarczego, można jednak odnieść wrażenie, że los biedoty żydowskiej leżał poza zasięgiem troski pisarki. Wątpliwości rozwiewa lektura opublikowanego przez nią w 1936 r. na łamach „Dziennika Popularnego” głośnego artykułu Doroczny wstyd. To w nim Dąbrowska po raz pierwszy wyraziła publicznie powtórzone 2 lata później na kartach broszury Ręce $w$ uścisku zdanie, iż „uszczuplenie praw jakichkolwiek mniejszości narodowych byłoby moralnie i politycznie klęska państwa polskiego" ${ }^{4}$. W tym wypadku nie mogło być wątpliwości, że także Żydów uważa za mniejszość narodową i przyznaje im pełnoprawne miejsce w polskim państwie wielonarodowym. Nie wiemy jednak, jak - zdaniem Dąbrowskiej - żydowska autonomia miałaby wyglądać w praktyce ${ }^{45}$.

Sytuacji nie ułatwia też to, w jaki sposób autorka Nocy i dni rozumiała pojęcie narodu i jaki miała do niego stosunek. Drewnowski najpewniej nie myli się pisząc:

dla Dąbrowskiej naród, podobnie jak człowieka, wyodrębnia jego osobowość, wyrastająca $z$ podłoża, z ziemi, z doświadczeń i wyrażająca się w obyczajach, obrzędach, wierzeniach, mowie. Pojęcie narodu wspiera się więc na więzi tradycjonalno-wspólnotowej ${ }^{46}$.

Naród - wspólnota historyczna - zdaje się być dla Dąbrowskiej wartością centralna (Drewnowski pisze o „polonocentryzmie” ${ }^{47}$ ), stanowiącą właściwy podmiot polityki. Nie jest to jednak tożsame $z$ postawą nacjonalistyczną, przynajmniej w jej

Zwraca na to uwagę także D r ew now ski (Węzty nie rozsupłane, s. 184).

M. D ą b r ow s ka, Doroczny wstyd. „Dziennik Popularny” 1936, nr 43, z 14 XI.

Projekty stworzenia autonomii narodowo-kulturalnej dla mniejszości żydowskiej w II Rzeczpospolitej omawia J. Ży nd ul w książce Państwo $w$ państwie? Autonomia narodowo-kulturalna $w$ Europie Środkowowschodniej $w$ XX wieku (Warszawa 2000, s. 83-156).

D r ew nows ki, Rzecz russowska, s. 258.

D rewnow ski, Węzty nie rozsupłane, s. 184. 
skrajnej postaci, gdyż nie łączy się $\mathrm{z}$ tak mocno wyrażaną ksenofobią i chęcią dominacji. Dąbrowskiej nie sposób wszakże zaliczyć do grona pozytywistów, zastępujacych etnocentryzm idea „,czystego człowieczeństwa” ${ }^{2}$, czy internacjonalistycznych socjalistów, hołdujących identyfikacji klasowej. Poparcie pisarki dla projektu wielonarodowej, obywatelskiej Polski było więc w jakiejś mierze wymuszone: wobec nierealności planów pozbycia się „problemu mniejszości” (poprzez asymilację czy emigracje) $\mathrm{w}$ interesie narodu polskiego leżało zbudowanie państwa, którego równoprawnymi, a przez to lojalnymi obywatelami byliby przedstawiciele różnych narodów.

Kończąc ten wątek, warto zauważyć, że taka romantyczna wizja narodu - jak nazywa ją Cała ${ }^{49}$ - narodu, który ma duszę i cechy niby pojedynczy człowiek, doskonale wpisuje się w to, co już zostało powiedziane o odczuwanej przez Dąbrowską, trudnej do określenia obcości Żydów zasymilowanych. Nie jest wszakże tak, że skłonność pisarki do doszukiwania się jednostkowych cech u grup narodowych czy etnicznych (dziś powiedzielibyśmy raczej o posługiwaniu się stereotypami czy uogólnieniami) przejawiała się tylko w jej stosunku do ludności żydowskiej. Być może nawet częściej zdarzało się wypowiadać Dąbrowskiej w ten sposób o Polakach, w których naturze leży np. skłonność do zrzucania winy na innych ${ }^{50}$, łatwość przechodzenia od bezinteresowności do pazerności ${ }^{51}$ czy nieumiejętność wyważonego krytykowania (istnienie tej polskiej „cechy narodowej” ponoć stwierdzał już Długosz, a kilkaset lat później piętnował Norwid 〈zob. RU 2〉).

\section{Zawstydzona Dąbrowska}

Gdy mowa o stosunku Dąbrowskiej do „kwestii żydowskiej”, nie można pominąc tego, w jaki sposób odnosiła się do narastającej od początku lat trzydziestych skali wystapień antysemickich i samego antysemityzmu. Sztandarowym jej tekstem poruszającym te kwestie jest wspomniany już Doroczny wstyd. Nie tylko po raz pierwszy napisała tam o odpowiedzialności szlachty czy w ogóle stosunków społecznych w dawnej Polsce za „nienormalny przerost sprawy żydowskiej” i opowiedziała się za równouprawnieniem i autonomią kulturalną Żydów (oraz innych mniejszości), ale potępiła też przemoc stosowaną wobec Żydów. Tytułowy „doroczny wstyd" to zbiegające się z początkiem roku akademickiego zamieszki studenckie, czyli wylewajaca się z uczelnianych bram na ulice „zaraza pogromowa”.

Dąbrowska nie przebierała w słowach: pisała o „barbarzyństwie rozbestwionej młodzieży”, „młodocianych pałkarzach” i o charakteryzujących ich „sercach jak gdyby jaskiniowych, mózgach jak gdyby ptasich”. Równą, a być może większą odpowiedzialnością za ekscesy antyżydowskie pisarka obarczała „oślepłych z nienawiści polityków" Stronnictwa Narodowego, kler katolicki, pedagogów, wykładowców

L. Sa d ow ski, Polska inteligencja prowincjonalna i jej ideowe dylematy na przełomie XIX i XX wieku (na przykładzie guberni łomżyńskiej, suwalskiej i Białegostoku). Warszawa 1988, s. 217.

49 C ała, op. cit., s. 287.

50 Zob. Dąbrowska, Doroczny wstyd.

51 Zob. M. Dąbrowska, Wielkanoc w Oksywiu. (1923). W: Pisma rozproszone. Red., przypisy E. Korzeniewska. T. 1. Kraków 1964, s. 257. 
akademickich, rodziców, wśród których „zdziczenie młodzieży nie tylko nie znajduje sprzeciwu, lecz na odwrót - poparcie, a w najlepszym razie milcząca życzliwa aprobatę". Prześmiewa również tłumaczenia, że bicie jest naturalną reakcją na przewiny Żydów, wynikającą $z$ „żywiołowości” młodziėzy.

Postawa Dąbrowskiej wobec prześladowań Żydów w latach trzydziestych nie jest wszakże tak jednoznacznie budująca, jak wynika to z Dorocznego wstydu. Wyraźnym cieniem kładzie się na niej komentarz, jaki dała 2 lata później, do zanotowanej w dzienniku, pod datą 21 XII 1938, rozmowy dentystki ze swoim siostrzeńcem, której musiała wysłuchać, siedząc w poczekalni. Siostrzeniec - niejaki Lusio - proponował, aby powywieszać masonów i zadeklamował „okropne językowo wierszydło podżegające do bicia "żydłaków". Komentując tę sytuację autorka dziennika napisała:

Widocznie tam u tego Lusia fabrykuje się te paskudztwa, uwłaczające polskiemu imieniu. (Bo zawsze idzie mi nade wszystko o Polaków - Żydzi sobie poradzą i wszystko z nawiązką nam odpłaca.) [D-4 105]

Wypowiedź ta ujawnia, że Dąbrowska skłonna była ulegać takim stereotypom na temat Żydów, jak ich bezgraniczna solidarność i spryt. Nie powinno to być zaskoczeniem. Co najmniej drugi $z$ wymienionych elementów stanowi logiczną konsekwencje omówionego już przekonania pisarki o szczególnej inteligencji, którą odznaczają się Żydzi. Wektory jednak się odwróciły - wcześniej domniemana inteligencja Żydów była w oczach Dąbrowskiej cechą pozytywną, teraz wisi nad Polakami niczym groźba. Lecz cytat ten mówi o czymś jeszcze ważniejszym: dla Dąbrowskiej antysemityzm jest niedopuszczalny nie dlatego, że krzywdzi on Żydów, ale dlatego, że negatywnie wpływa na Polaków. Problem nie leży więc w niechęci Polaków do Żydów - w domyśle: przynajmniej w jakiejś części uzasadnionej - tylko $\mathrm{w}$ niedopuszczalnych $\mathrm{z}$ moralnego punktu widzenia metodach walki.

Przytoczony komentarz Dąbrowskiej to bardzo dobitny wyraz postrzegania przez nią Żydów jako obcych. Wydaje się ono jednak także próbą usprawiedliwienia się pisarki przed atakującymi ją nieustannie od czasów opublikowania Dorocznego wstydu oponentami, podpierającymi prawą ścianę sceny politycznej.

W październiku 1938 w tygodniku „Prosto z Mostu” ukazała się ostra napaść na Dąbrowską jako prezesa warszawskiego oddziału Związku Literatów Polskich. Autor tekstu wytknął pisarce, że w okólniku informującym o powołaniu zespołu lekarzy, który zgodził się leczyć ubogich literatów po preferencyjnych cenach, aż połowa wymienionych nazwisk jest żydowska. Dąbrowska uznała ten fakt za swoje niedopatrzenie i skłonna była się wycofać, aby - jak zapisała 29 X 1938 - nie „prowokować bestii ludzkiej, gdy nie mamy w tej chwili siły do jej zniszczenia”, zwłaszcza że „psy endeckie tylko czekają na każdą, by najmniejszą taką okazję, by zohydzać Związek i moje nazwisko" (D-4 89). Wobec antysemickiej atmosfery, gęstniejącej w ostatnich latach przed wybuchem wojny, autorka Dorocznego wstydu zdecydowała się na kapitulację.

Postawa Marii Dąbrowskiej wobec Żydów cechuje się na pierwszy rzut oka brakiem konsekwencji. $Z$ jednej strony, $z$ prywatnych zapisków autorki Nocy $i$ dni wynika wyraźnie, że nie była wolna od antysemickich stereotypów, a Żydów, także tych zasymilowanych, postrzegała jako obcych. $Z$ drugiej - energicznie walczyła piórem 
z tymi uprzedzeniami względem ludności wyznania mojżeszowego, których sama nie podzielała. $Z$ dużą siła występowała też w obronie prześladowanych Żydów, a do „kwestii żydowskiej” podchodziła w białych rękawiczkach, proponując rozwiązanie, którego istotą nie była antyżydowskość.

Niekonsekwentny stosunek do Żydów to nic zaskakującego - wiele antysemickich schematów, często wypowiadanych jednym tchem, wzajemnie się wyklucza. W przypadku Dąbrowskiej ów brak konsekwencji jest wszelako w jakiejś części pozorny. Za nić spajająca w całość stosunek autorki Nocy i dni do Żydów można właściwe uznać jej przekonanie, iż podstawową wartość stanowi dobro narodu polskiego. Tak więc bicie Żydów nie dlatego było złe, a przynajmniej nie tylko dlatego, że wiązało się z cierpieniem Żydów, lecz dlatego, że rujnowało morale Polaków. Poparcie Dabrowskiej dla projektu Polski obywatelskiej nie wynikało z humanistycznych zapatrywań pisarki, ale $z$ oceny - całkiem zresztą trzeźwej - że zaniechania w budowie równościowego społeczeństwa wielokulturowego Polskę rozerwą.

Abstract

CYRYL SKIBIŃSKI Warsaw

\section{PAPER SEGREGATION MARIA DABROWSKA'S ATTITUDE TOWARDS THE JEWS}

Maria Dabrowska's attitude towards the Jews was quite ambiguous. On the one hand, throughout her whole life she declared her enmity to anti-Semitism, and before the war she publicly condemned anti-Jewish aggression. On the other hand, her diary and letters makes their reader realise how alien the Jews seemed to her. Orthodox, poor Jews filled her with disgust and only rarely did the aversion retreat and its place was taken by interest in the exoticism of everyday shtetl life.

Dąbrowska, however, did not distance only from small-town religious Jews. She expressed marked reservation also to deeply assimilated Polish cultural life members of Jewish origin. In her diary she meticulously and with great suspiciousness noted Jewish origin of people she met a given day. They were also to some extend alien to her.

Solving "the Jewish case" was important, though by no means leading element of Dabrowska's social publicist writing. She saw the source of tensions between Jewish minority and Polish majority rather in social historical circumstances than in deliberate activities of any party. Being against settlement by force, she also rejected a simple contradiction: either assimilation or emigration. As if against her prejudice, or above it, she inclined towards Poland of multinational citizens. 